\title{
Karakteristik Tes Keterampilan Proses Sains: Validitas, Reliabilitas, Tingkat Kesukaran dan Daya Pembeda Soal
}

\author{
Sri Lestari Handayani ${ }^{1}$, Khairil Iba ${ }^{2}$ \\ ${ }^{1,2}$ Pendidikan Guru Sekolah Dasar, Fakultas Keguruan dan Ilmu Pendidikan, Universitas \\ Muhammadiyah Prof. DR. HAMKA \\ ${ }^{1}$ srilestarih@uhamka.ac.id
}

\begin{abstract}
ABSTRAK
Penelitian ini bertujuan untuk menganalisis karakteristik instrumen tes keterampilan proses sains (KPS) yang telah dikembangkan meliputi validitas, reliabilitas, tingkat kesukaran dan daya pembeda soal. Metode penelitian ini adalah penelitian deskriptif. Data diperoleh dengan menggunakan tes. Data dianalisis dengan rasch model menggunakan winstep rasch. Hasil penelitian ini diperoleh 24 soal berkategori valid dan 1 soal berkategori tidak valid. Reliabilitas tes secara keseluruhan sebesar 0,66 berkategori cukup, sedangkan relibilitas butir soal sebesar 0,99 berketagori istimewa. Persebaran tingkat kesukaran butir tes diperoleh hasil terdapat 6 soal yang berkategori sulit, 6 soal berkategori sedang, dan 13 soal yang berkategori mudah. Tes kemampuan keterampilan proses sains tidak memiliki butir soal yang bias karena semua nilai probabilitas pada setiap butir soal lebih dari 0,05 .
\end{abstract}

Kata kunci: keterampilan proses sains; validitas, reliabilitas, tes pilihan ganda beralasan, rasch model

\section{ABSTRACT}

This study aims to analyze the characteristics of the science process skills test instruments that have been developed including validity, reliability, difficulty level and distinguishing features of the questions. This research method is descriptive research. Data obtained using tests. Data were analyzed with the Rasch Model using Winstep Rasch. The results of this study were obtained there are 24 valid questions and 1 invalid question. Overall test reliability of 0.66 is sufficient, while the item reliability of 0.99 has a special category. The distribution of the level of difficulty of the test items obtained results there are 6 questions that are categorized as difficult, 6 questions categorized as moderate, and 13 questions that are categorized as easy. The ability test of science process skills does not have biased items because all probability values on each item are more than 0.05.

Keywords:: science process skills; validity, reliability, reasoned multiple choice test, rasch model

\section{PENDAHULUAN}

Keterampilan proses sains wajib dimiliki oleh guru sebelum guru tersebut memberikan kesempatan kepada siswa untuk menumbuhkan keterampilan proses sainsnya. Guru harus memahami keterampilan proses sains yang dimilikinya beserta kelemahankelemahannya. Hal tersebut berlaku bagi calon pendidik. Calon pendidik termasuk calon guru Sekolah Dasar (SD) diharapkan memiliki keterampian proses sains yang baik sehingga dapat menciptakan pembelajaran sains di Sekolah Dasar dengan berfokus mengembangkan proses sains siswa. Ango (2002) menyatakan bahwa komponen mendasar dan kritis di dalam mengajarkan sains adalah keterampilan proses sains. Apabila seorang calon guru SD tidak mampu membuat suatu pembelajaran yang tepat maka keterampilan proses sains siswa tidak akan berkembang secara optimal. Pembelajaran yang berfokus pada pengembangan keterampilan proses sains siswa memiliki dampak positif bagi siswa tersebut dalam mempelajari sains, diantaranya keterampilan proses sains siswa memberi pengaruh positif meningkatnya hasil belajar siswa tersebut (Abungu, et al. 2014), dan pembelajaran dengan menitikberatkan pada keterampilan proses sains dapat membantu mencapai ketuntasan belajar siswa secara efektif (Anisa, et. al. 2014).

Untuk itulah kemampuan seorang guru dalam membuat dan menciptakan proses pembelajaran berbasis keterampilan proses sains menjadi penentu. Kemampuan mencipta 
pembelajaran berbasis sains bermula dari seorang calon guru yang memiliki keterampilan proses sains yang baik pula. Hal ini sejalan dengan penelitian (Aydogdu, et. Al. 2014) yang menyatakan bahwa keterampilan proses sains seorang guru bertanggungjawab terhadap keterampilan mengajar yang digunakan didalam kelas. Pernyataan serupa dikemukakan oleh Agoro \& Akinsola (2013), guru berperan positif dalam pengembangan keterampilan proses sains siswa jika guru tersebut mampu menggunakan pembelajaran yang tepat. Guru yang memiliki pemahaman tentang keterampilan proses sains yang baik maka guru tersebut dapat membantu siswa meningkatkan ketarampilan proses sains siswanya ke tingkat yang lebih baik (Aydogdu, et al., 2014; Mutisya, et al., 2013). Keterampilan proses sains wajib dimiliki oleh calon guru sebelum calon guru menciptakan kesempatan kepada siswanya untuk menumbuhkan dan meningkatkan keterampilan proses sains siswa. Untuk mengetahui keterampilan proses sains calon guru khususnya calon guru SD maka diperlukan alat evaluasi yang khusus untuk mengukur keterampilan proses sains mahasiswa calon guru tersebut. Untuk mengukur keterampilan proses sains dapat dengan observasi (Azizah, et al. 2018; Sudibyo, et. al. 2019), rubrik assesmen dengan skala likert (Wati \& Novianti, 2016), dan atau tes (Suryani, et. al. Fadillah, 2017; Azizah, et. al. 2018; Haniah, Annisa \& Kartini, 2018; Nurhayati, Saputri \& Assegaf, 2019;). Pada penelitian ini dikembangkan instrumen tes pilihan ganda berasalan yang diciptakan untuk mengukur keterampilan proses sains mahasiswa calon guru SD khususnya pada materi listrik.

Beberapa penelitian pengembangan instrumen tes untuk mengukur keterampilan proses sains sebelumnya diantaranya Haniyah Annisa \& Kartini (2018) mengembangkan 30 soal pilihan ganda dimana analisisnya menggunakan software SPSS dan Anates, Nurhayati, Saputri \& Assegaf (2019) yang mengembangkan tes keterampilan proses sains berupa kombinasi antara pilihan ganda beralasan dan essay, Widayanti (2016) mengembangkan tes pilihan ganda untuk mengukur keterampilan proses sains siswa, Fadillah (2017) yang mengembangkan instrumen tes keterampilan proses sains pada tingkat Sekolah Menengah Atas (SMA) dengan menggunakan analisis Aiken's $\mathrm{V}$ dan QUEST, dan Damayanti, Yamtinah \& Utomo
(2018) yang mengembangkan tes pilihan ganda dua tingkat untuk mengukur keterampilan proses sains siswa pada materi optik.

Salah satu alat evaluasi yang dapat digunakan untuk mengukur keterampilan proses sains mahasiswa yaitu tes pilihan ganda beralasan. Fadillah (2017) mengembangkan tes pilihan ganda beralasan pada mata pelajaran biologi dimana dikembangkan sebanyak 23 soal dimana analisisnya mengunakan Aiken's $\mathrm{V}$ dan QUEST. Perbedaan instrumen tes yang dikembangkan pada penelitian ini dengan penelitian-penelitian sebelumnya terletak pada materi yaitu (1) instrumen dikhususkan untuk materi listrik, (2) tes berbentuk pilihan ganda beralasan dimana alasannya terbuka bukan berupa pilihan alasan, (3) penentuan validitas, reliabilita, tingkat kesukaran soal, daya pembeda soal menggunakan Rasch Model.

Melalui pengembangan alat evaluasi keterampilan proses sains berupa tes pilihan ganda beralasan yang tepat diharapkan mampu memberi gambaran keterampilan proses sains mahasiswa calon guru SD. Tujuan penelitian ini adalah (1) Untuk mengetahui validitas tes KPS yang dikembangkan dengan analisis Rasch Model, (2) Untuk mengetahui reliabilitas tes KPS yang dikembangkan dengan analisis Rasch Model, dan (3) Untuk mengetahui tingkat kesukaran tes KPS yang dikembangkan dengan analisis Rasch Model, dan (4) untuk mengetahui tes KPS yang dikembangkan dengan analisis Rasch Model.

METODE PENELITIAN
Penelitian ini berawal dari pengembangan instrumen tes keterampilan proses sains (KPS) untuk calon guru SD. Produk awal instrumen tes KPS yang dibuat terdiri dari 25 soal yang mengukur keterampilan proses sains dasar sebanyak 6 indikator yaitu 5 soal mengukur indikator mengamati, 4 soal mengukur indikator merumuskan hipotesis, 3 soal mengukur indikator merencanakan penelitian atau percobaan, 4 soal untuk mengukur meramal atau memprediksi, dan 5 soal untuk mengukur indikator menerapkan konsep. Penelitian ini merupakan penelitian deskriptif untuk deskripsikan karakteristik tes keterampilan proses sains yang dikembangkan berupa validitas tes, reliabilitas tes, tingkat kesukaran soal, dan daya pembeda soal. Sampel penelitian ini untuk uji coba tes KPS yang dikembangkan sebanyak 80 mahasiswa calon guru SD. Sampel diambil secara random. Data diambil dengan dengan tes KPS. Untuk 
menentukan karakteristik tes KPS yang dikembangkan dianalisis menggunakan Rasch Model dengan aplikasi Winstep Rasch.

\section{HASIL \& PEMBAHASAN}

Berdasarkan analisis

data menggunakan Rasch Model, diperoleh hasil validitas tes, reliabilitas tes, tingkat kesukaran tes dan kebiasan atau daya pembeda tes Ketrampilan Proses Sains (KPS) yang dikembangkan.

\section{Validitas Tes}

Pengujian validitas tes KPS yang dikembangkan dengan Rasch Model berdasarkan nilai Outfit Mean Square (MNSQ), Outfit Z-Standard (ZSTD), dan Point
Measure Correlation (Pt Mean Corr). Setiap butir tes dikatakan valid jika memiliki kriteria berikut (Sumintono \& Widhiarso, 2013): (1) Nilai Outfit Mean Square (MNSQ) yang diterima: $0,5<$ MNSQ $<1,5$; (2) Nilai Outfit Z-Standard (ZSTD) yang diterima: $-2,0<$ ZSTD $<+2,0$; dan (3) Nilai Point Measure Correlation (Pt Mean Corr): 0,4 $<\mathrm{Pt}$ Mean Corr $<0,85$. Bila butir tes kemampuan proses sains memenuhi setidaknya salah satu kriteria diatas, maka butir soal atau pernyataan tersebut dapat digunakan, dengan kata lain butir tersebut valid. Analisis dengan Rasch Model diperoleh validitas yang tampak pada Tabel 1 berikut.

Tabel 1. Hasil Uji Validitas Tes Ketrampilan Proses Sains

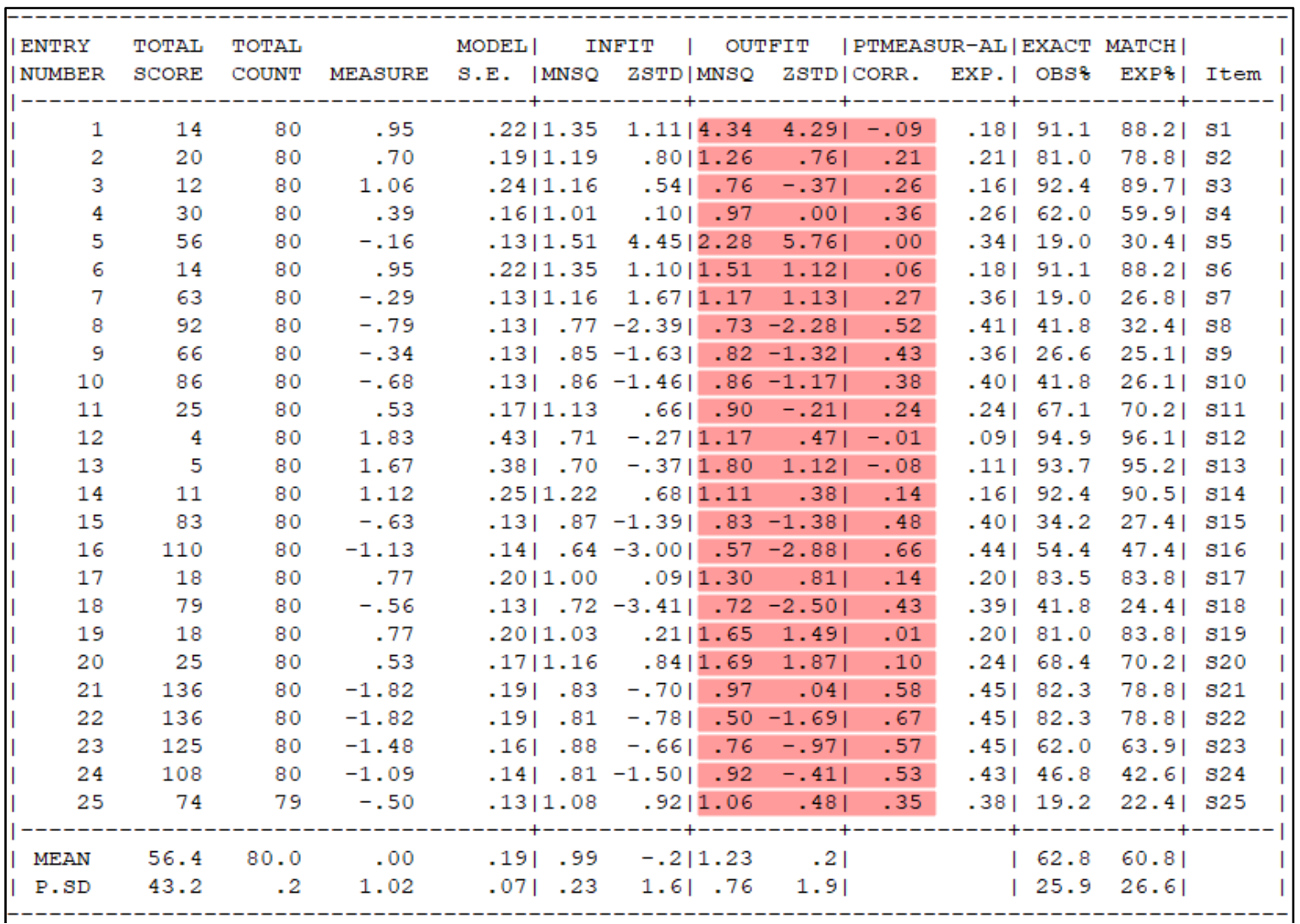

Berdasarkan kriteria validitas yang telah ditetapkan sebelumnya, hasilnya menunjukkan bahwa terdapat satu soal yang tidak valid yaitu soal no 1 karena nilai Nilai Outfit Mean Square (MNSQ) 4,34, Outfit ZStandard (ZSTD) 4,29 dan Point Measure Correlation sebesar $-0,09$ yang berarti tidak sesuai dengan kriteria. Untuk soal yang lainnya dapat dinyatakan valid karena memenuhi salah satu kriteria yang telah ditentukan. Hasil uji validitas ini menunjukkan bahwa dari 25 soal yang dikembangkan, terdapat 1 soal yang tidak valid yaitu soal nomor 1. Dapat dinyatakan bahwa soal ini tidak dapat mengukur indikator mengamati yaitu memilih gambar komponen dan rangkaian listrik dengan benar.

\section{Reliabilitas Tes}

Hasil yang diperoleh dari uji reliabilitas tes ketrampilan proses sains menggunakan Rasch model dapat dilihat pada Tabel 2 berikut. 
Tabel 2. Hasil Uji Relibilitas Butir Soal

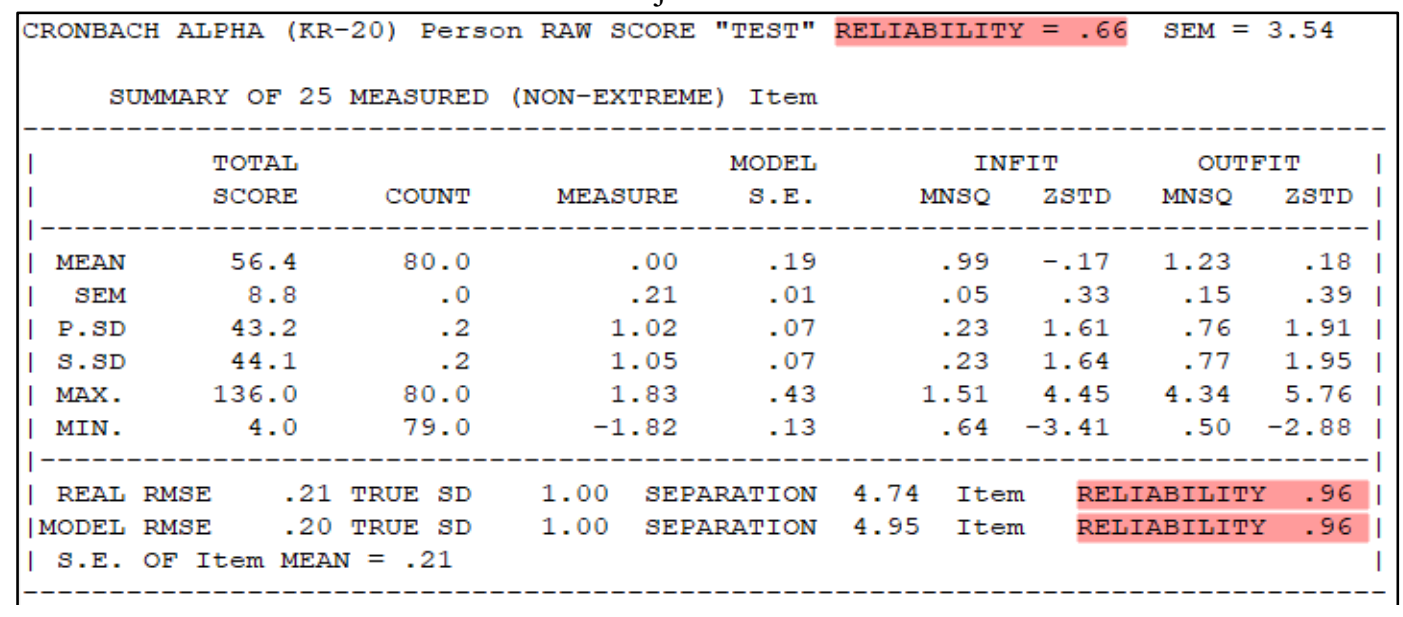

Hasil pada Tabel 2 tersebut menunjukkan bahwa nilai alpha cronbach yang diperoleh pada relibilitas keseluruhan tes kemempuan keterampilan proses sains adalah 0,66. Nilai tersebut termasuk dalam kategori cukup. Dalam analisis menggunakan Rasch Model, diberikan pula nilai reliabilitas butir soal. Pada Tabel 2 di atas, terlihat bahwa nilai reliabilitas butir soal adalah 0,96. Dengan demikian nilai reliabilitas pada butir item ini

Tabel 3. Hasil Uji Tingkat Kesukaran Tes Ketrampilan Proses Sains

\begin{tabular}{|c|c|c|c|c|}
\hline \multicolumn{2}{|c|}{$\begin{array}{l}\text { I ENTRY } \\
\text { | NUMBER }\end{array}$} & $\begin{array}{l}\text { TOTAL } \\
\text { SCORE }\end{array}$ & $\begin{array}{l}\text { TOTAL } \\
\text { COUNT }\end{array}$ & MEASURE \\
\hline \multirow{2}{*}{\multicolumn{5}{|c|}{$1------1$}} \\
\hline & & 4 & 80 & 1.83 \\
\hline I & 13 & 5 & 80 & 1.67 \\
\hline I & 14 & 11 & 80 & 1.12 \\
\hline I & 3 & 12 & 80 & 1.06 \\
\hline I & 1 & 14 & 80 & .95 \\
\hline I & 6 & 14 & 80 & .95 \\
\hline I & 17 & 18 & 80 & -77 \\
\hline I & 19 & 18 & 80 & -77 \\
\hline I & 2 & 20 & 80 & .70 \\
\hline I & 11 & 25 & 80 & .53 \\
\hline I & 20 & 25 & 80 & .53 \\
\hline I & 4 & 30 & 80 & .39 \\
\hline I & 5 & 56 & 80 & -.16 \\
\hline I & 7 & 63 & 80 & -.29 \\
\hline I & 9 & 66 & 80 & -.34 \\
\hline I & 25 & 74 & 79 & -.50 \\
\hline I & 18 & 79 & 80 & -.56 \\
\hline I & 15 & 83 & 80 & -.63 \\
\hline I & 10 & 86 & 80 & -.68 \\
\hline I & 8 & 92 & 80 & -.79 \\
\hline I & 24 & 108 & 80 & -1.09 \\
\hline I & 16 & 110 & 80 & -1.13 \\
\hline I & 23 & 125 & 80 & -1.48 \\
\hline I & 21 & 136 & 80 & -1.82 \\
\hline I & 22 & 136 & 80 & -1.82 \\
\hline & ------- & ------ & ----- & -------- \\
\hline I & MEAN & 56.4 & 80.0 & .00 \\
\hline I & P.SD & 43.2 & -2 & 1.02 \\
\hline
\end{tabular}

Berdasarkan Tabel 3 di atas, nilai measure menunjukkan urutan soal dari yang tersulit sampai soal termudah. Butir dengan nomor soal 12 merupakan soal yang tersulit. Butir soal nomor 22 adalah soal dengan dinyatakan pada katagori istimewa berdasarkan kriteria Sumintono \& Widhiarso (2013).

\section{Tingkat Kesukaran Soal}

Berdasarkan hasil analisis dengan Rasch Model disajikan urutan butir soal dari yang tersulit sampai pada butir soal yang termudah. Hasil uji tingkat kesulitan butir soal ketrampilan proses sains pada Tabel 3 berikut.

kategori paling mudah bagi mahasiswa. Nilai kategori kesukaran butir soal dapat pula dilihat melalui Peta wright person item. Hasil peta wright person item dapat dilihat pada Gambar 1 berikut. 


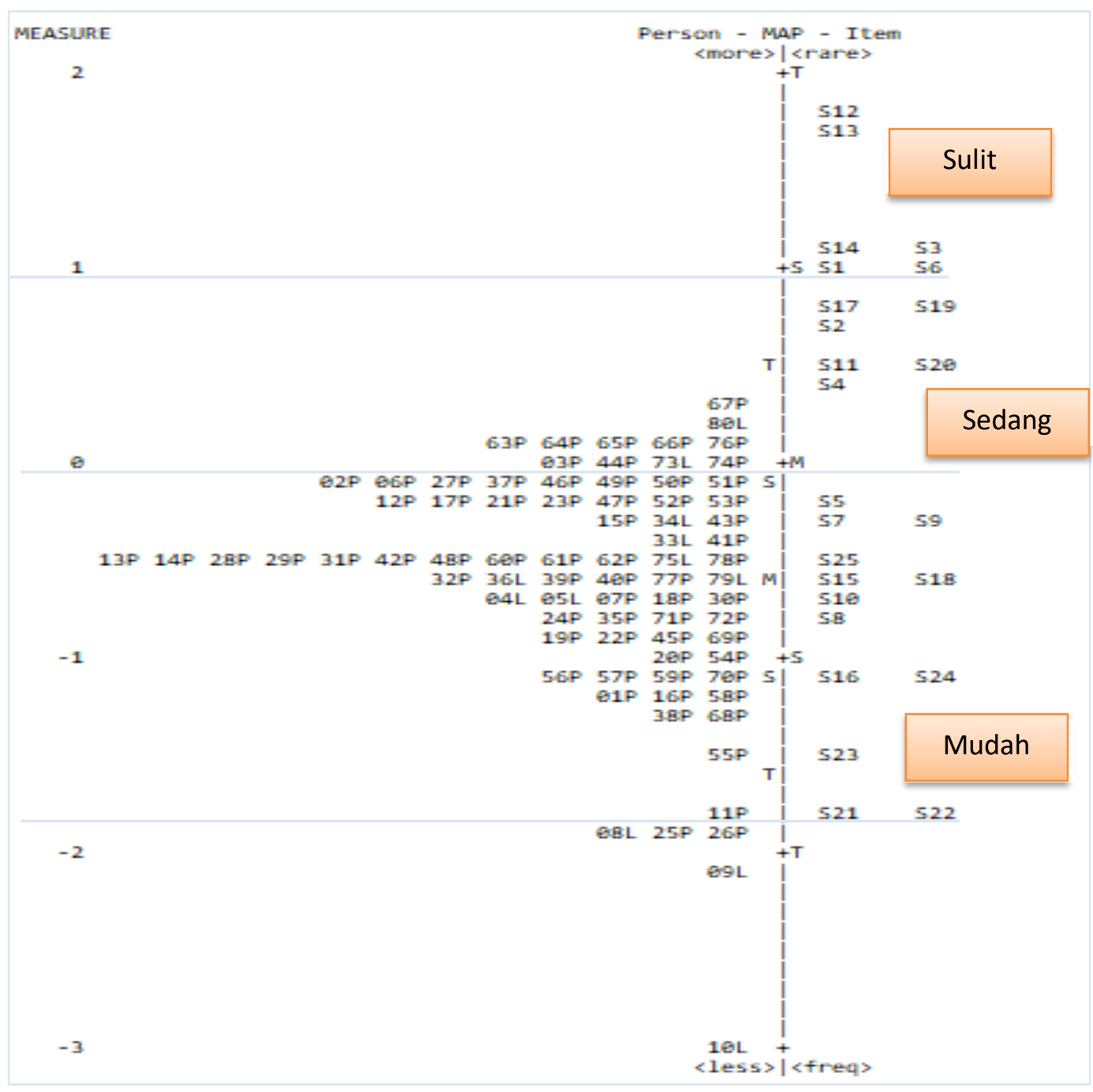

Gambar 1. Persebaran Tingkat Kesukaran Soal KPS dengan Peta Wright Person Item

Berdasarkan Gambar 1 tersebut, diperoleh informasi bahwa terdapat 6 soal yang berkategori sulit, 6 soal berkategori sedang, dan 13 soal yang berkategori mudah. Soal yang berkategori sulit merupakan soal-soal yang hanya dapat dikerjakan oleh mahasiswa berkategori memiliki ketrampilan proses sains tinggi yaitu pada soal nomor $1,3,6,12,13$, dan 14. Soal yang berkategori sedang merupakan soal-soal yang dapat dikerjakan dengan mudah oleh mahasiswa yang memiliki ketrampilan proses sains tinggi, namun untuk sebagian mahasiswa yang memiliki ketrampilan proses sains rendah tergolong cukup sulit. Butir soal yang berkategori sedang adalah soal nomor 2, 4, 11, 17, 19, dan 20. Soal yang berkategori memiliki tingkat kesukaran rendah adalah soal nomor 5, 7, 8, 9, $10,15,16,18,21,22,23,24$, dan 25. Soal yang berkategori rendah memiliki arti bahwa soal-soal ini dapat dikerjakan oleh hampir seluruh mahasiswa calon guru SD.

\section{Daya Pembeda Soal}

Daya Pembeda soal untuk setiap butir soal dilihat dari nilai DIFnya atau nilai kebiasan butir soal. Hasil uji kebiasan butir soal dapat dilihat pada Tabel 4 berikut. 
Tabel 4. Hasil Uji Kebiasan Butir Soal Tes KPS

\begin{tabular}{|c|c|c|c|c|c|c|c|c|c|}
\hline \multirow{2}{*}{\multicolumn{2}{|c|}{$\begin{array}{l}\text { | Person } \\
\text { | CLASSES }\end{array}$}} & SUMMARY DIF & & & \multicolumn{2}{|c|}{ BETWEEN-CLASS/GROUP } & \multicolumn{2}{|l|}{ Item } & I \\
\hline & & CHI-SQUARED & D.F. & PROB. & UNWTD MNSQ & ZSTD & Number & Name & | \\
\hline | & 2 & .0072 & 1 & .9322 & .0084 & -1.22 & 1 & s1 & \\
\hline | & 2 & 2.8247 & 1 & .0928 & 3.5701 & 1.59 & 2 & $\mathrm{~s} 2$ & \\
\hline | & 2 & 2.3425 & 1 & .1259 & 2.9294 & 1.39 & 3 & s3 & \\
\hline | & 2 & 2.9708 & 1 & .0848 & 3.7427 & 1.64 & 4 & $\mathrm{~s} 4$ & \\
\hline | & 2 & 2.7343 & 1 & .0982 & 3.3806 & 1.53 & 5 & s5 & \\
\hline | & 2 & .8224 & 1 & .3645 & 1.5218 & .79 & 6 & $\mathrm{~s} 6$ & \\
\hline | & 2 & 2.3023 & 1 & .1292 & 2.8406 & 1.35 & 7 & 57 & \\
\hline | & 2 & 1.1403 & 1 & .2856 & 1.2787 & .65 & 8 & $\mathbf{s} 8$ & \\
\hline | & 2 & .0110 & 1 & .9165 & .0130 & -1.15 & 9 & s9 & \\
\hline | & 2 & .3878 & 1 & .5335 & .4153 & -.07 & 10 & $\mathrm{~s} 10$ & \\
\hline | & 2 & .4183 & 1 & .5178 & .4564 & -.02 & 11 & s11 & \\
\hline | & 2 & .1267 & 1 & .7219 & .4454 & -.03 & 12 & $\mathrm{~S} 12$ & \\
\hline | & 2 & .1995 & 1 & .6551 & .5485 & .09 & 13 & $\mathrm{~S} 13$ & \\
\hline | & 2 & .6317 & 1 & .4267 & 1.1844 & .59 & 14 & $\mathrm{~S} 14$ & \\
\hline | & 2 & .5827 & 1 & .4452 & .6315 & .17 & 15 & S15 & \\
\hline | & 2 & 1.0301 & 1 & .3101 & 1.1388 & .57 & 16 & $\mathrm{~S} 16$ & \\
\hline | & 2 & .0427 & 1 & .8363 & .0533 & -.85 & 17 & $\mathrm{~S} 17$ & \\
\hline | & 2 & .0216 & 1 & .8831 & .0266 & -1.02 & 18 & $\mathrm{~S} 18$ & \\
\hline | & 2 & 1.9791 & 1 & .1595 & 2.3798 & 1.18 & 19 & S19 & \\
\hline | & 2 & .0201 & 1 & .8872 & .0259 & -1.02 & 20 & $\mathrm{~S} 20$ & \\
\hline | & 2 & .2982 & 1 & .5850 & .3162 & -.20 & 21 & $\mathrm{~s} 21$ & \\
\hline । & 2 & .2982 & 1 & .5850 & .3162 & -.20 & 22 & $\mathrm{~s} 22$ & \\
\hline | & 2 & 1.2622 & 1 & .2612 & 1.4031 & .72 & 23 & $\mathrm{~S} 23$ & \\
\hline । & 2 & .8044 & 1 & .3698 & .8825 & .38 & 24 & $\mathrm{~S} 24$ & \\
\hline | & 2 & 3.5357 & 1 & .0601 & 11.2986 & 3.11 & 25 & $\mathrm{~S} 25$ & \\
\hline
\end{tabular}

Berdasarkan Tabel 4 tersebut, secara umum dapat dinyatakan bahwa tes keterampilan proses sains tidak memiliki butir soal yang bias karena semua nilai probabilitas pada setiap butir soal lebih dari 0,05 . Soal dinyatakan tidak bias jika soal tersebut tidak membuat salah satu individu lebih diuntungkan.

Secara umum berdasarkan uji validitas, reliabilitas, tingkat kedukaran soal dan daya pembeda soal dapat dinyatakan bahwa instrumen tes Keterampilan Proses Sains (KPS) Materi Listrik dinyatakan valid dan reliabel. Instrumen KPS yang dikembangkan dapat mengukur Ketrampilan Proses Sains Mahasiswa calon guru dengan baik. Instrumen KPS yang dikembangkan menghasilkan 24 soal valid.

\section{KESIMPULAN \& SARAN}

Instrumen tes KPS yang dikembangkan menghasilkan 25 soal. Berdasarkan hasil penelitian diperoleh 24 soal berkategori valid dan 1 soal berkategori tidak valid. Reliabilitas tes secara keseluruhan sebesar 0,66 berkategori cukup, sedangkan relibilitas butir soal sebesar 0,99 berkategori istimewa. Persebaran tingkat kesukaran butir tes diperoleh hasil terdapat 6 soal yang berkategori sulit, 6 soal berkategori sedang, dan 13 soal yang berkategori mudah. Tes kemampuan keterampilan proses sains tidak memiliki butir soal yang bias karena semua nilai probabilitas pada setiap butir soal lebih dari 0,05 .

Berdasarkan hasil penelitian ini maka perlu tindak lanjut berupa penerapan tes tersebut untuk menentukan ketrampilan proses sains mahasiswa calon guru SD. Selain itu, perlu perbaikan-perbaikan yang dilakukan sehingga diperoleh instrumen yang semakin baik dan uji coba untuk skala yang lebih luas.

\section{DAFTAR PUSTAKA}

Abungu, H. E., Okere, M. I., \& Wachanga, S. W. (2014). The effect of science process skills teaching approach on secondary school students' achievement in chemistry in Nyando district, Kenya. Journal of Educational and Social Research, 4(6), 359.

Agoro, A. A., \& Akinsola, M. K. (2013). Effectiveness Of Reflective-Reciprocal Teaching On Pre-Service Teachers' Achievement And Science Process Skills In Integrated Science. International journal of education and research, 1(8), 1-20. 
Ango, M. L. (2002). Mastery of Science Process Skills and Their Effective Use in the Teaching of Science: An Educology of Science Education in the Nigerian Context. International Journal of Educology, 16(1).

Anisa, T. M., Supardi, K. I., \& Sedyawati, S. M. R. (2014). Keefektifan Pendekatan Keterampilan Proses Sains Berbantuan Lembar Kerja Siswa pada Pembelajaran Kimia. Jurnal Inovasi Pendidikan Kimia, 8(2).

Aydoğdu, B., Erkol, M., \& Erten, N. (2014, June). The investigation of science process skills of elementary school teachers in terms of some variables: Perspectives from Turkey. In Asia-Pacific Forum on Science Learning \& Teaching, 15 (1).

Azizah, K. N., Ibrahim, M., \& Widodo, W. (2018). Process Skill Assessment Instrument: Innovation to measure student's learning result holistically. Journal of Physics: Conference Series, 947 (1).

Damayanti, D. R., Yamtinah, S., \& Utomo, S. B. Pengembangan Instrumen Penilaian Two-Tier Multiple Choice Question Untuk Mengukur Keterampilan Proses Sains Siswa Pada Tema Mata Sebagai Alat Optik. INKUIRI: Jurnal Pendidikan IPA, 7(2), 252-261.

Fadillah, E. N. (2017). Pengembangan instrumen penilaian untuk mengukur keterampilan proses sains siswa SMA. Didaktika Biologi: Jurnal Penelitian Pendidikan Biologi, 1(2), 123134.

Haniah, F., Annisa, M., \& Kartini, K. (2018). Pengembangan Instrumen Tes Berbasis Keterampilan Proses Sains Pada Materi Benda dan Sifatnya Kelas V SDN 010 Tarakan. Widyagogik: Jurnal Pendidikan dan Pembelajaran Sekolah Dasar, 6(1), 29-46.

Mutisya, S. M., Stephen R., dan Paul K. R. (2013). Conceptual Understanding Of Science Process Skills And Gender Stereotyping: A Critical Component For Inquiry Teaching Of Science In Kenya's Primary Schools. Asian Journal of Social Sciences and Humanities, 2(3), 359 - 369.

Nurhayati, N., Saputri, D. F., \& Assegaf, S. L. H. (2019). Pengembangan Instrumen Tes Keterampilan Proses Sains Pada Materi Fisika untuk Siswa Sekolah Menengah
Pertama. Edukasi: Jurnal Pendidikan, 17(2), 145-158.

Sudibyo, E., Naini, A. F., \& Sabtiawan, W. B. (2020). The Effectiveness of Student Worksheet to Train Science Process Skills. Jurnal Penelitian Pendidikan IPA, 4(2), 70-74.

Suryani, A., Siahaan, P., \& Samsudin, A. (2015). Pengembangan instrumen tes untuk mengukur keterampilan proses sains siswa SMP pada materi gerak. Prosiding Simposium Nasional Inovasi dan Pembelajaran Sains 2015 217-220.

Wati, W., \& Novianti, N. (2016). Pengembangan Rubrik Asesmen Keterampilan Proses Sains pada Pembelajaran IPA SMP. Jurnal Ilmiah Pendidikan Fisika Al-Biruni, 5(1), 131140.

Widayanti, E. Y. (2016). Pengembangan tes keterampilan proses sains dasar $\mathrm{SD} / \mathrm{MI}$. Journal of Islamic Elementary School, 1(2), 73-88. 